\title{
Chemical Control of Male Pre-pupae and Adult Females of Margarodes prieskaensis (Jakubski) (Coccoidea : Margarodidae) on Grapevines
}

\author{
C.A. de Klerk \\ ARC Infruitec-Nietvoorbij, Private Bag X5026, 7599 Stellenbosch, South Africa \\ E-mail address: annette8@telkomsa.net
}

Submitted for publication: December 2009

Accepted for publication: May 2010

Key words: Margarodes, neonicotinoids, contact, fumigant pesticides

\begin{abstract}
Various contact, fumigant and systemic pesticides were evaluated over three years in a field trial for the control of male pre-pupae and adult females of Margarodes prieskaensis on grapevines. Cadusafos at $25 \mathrm{~mL} / \mathrm{m}^{2}$ gave excellent control of male pre-pupae. Pre-pupae, as well as adult females, were effectively controlled by dichloropropene at $15 \mathrm{~mL} / \mathrm{m}^{2}$, as well as by thiamethoxam at $2.4 \mathrm{~mL} / \mathrm{m}^{2}$ and $2.0 \mathrm{~mL} / \mathrm{m}^{2}$ and imidacloprid at $15 \mathrm{~mL} / \mathrm{m}^{2}, 3.0 \mathrm{~mL} / \mathrm{m}^{2}$ and $1.5 \mathrm{~mL} / \mathrm{m}^{2}$. Contact and fumigant applications were made during March and April (beginning of leafdrop), and systemics during January (one month after harvest). Chlorpyrifos, furfural, fenamiphos, carbofuran and terbufos were found to be ineffective for the control of $M$. prieskaensis.
\end{abstract}

\section{INTRODUCTION}

Numerous species of the genus Margarodes (ground pearls) occur on a wide range of host plants throughout most of the world (BenDov, 2005). Grapevine-infesting species, however, have only been reported from North and South America and from South Africa (De Klerk, 1985). Ten species of Margarodes occur in South Africa, five of which infest vine roots in most of the vinegrowing areas of South Africa. All vine-infesting species are of economic importance, and vines could even be killed within four years after planting in infested soil (De Klerk, 1985).

Margarodes prieskaensis is one of the main vine-infesting species and occurs in all the vine-growing areas along the Orange River in the Northern Cape (De Klerk, 1985). This is the only species in South Africa in which males and females congregate above ground for mating. According to Du Toit (1975) and De Klerk and Vermeulen (2007), the life cycle of M. prieskaensis on vines is as follows: The nymphs that feed on the roots are enclosed in a hard, pearl-like cyst and are present throughout the year. During April, male pre-pupae develop from the cysts and burrow up through the soil where they moult and pupate $20 \mathrm{~mm}$ to $30 \mathrm{~mm}$ beneath the soil surface. The pupae moult into winged male adults and appear above the ground from June to August. From the beginning of June, adult females emerge from the mature cysts and burrow directly to the soil surface. After mating, the males die and the females burrow down into the soil to deposit their eggs in the vicinity of the roots. After hatching, the nymph inserts its stylets into a suitable root for feeding and starts secreting layers of hard wax to form the cyst. One generation is completed each year.

In field trials conducted in the Orange River irrigation area between 1982 and 1985, various pesticides were evaluated. Hexachlorobutadiene at a rate of $12 \mathrm{~mL} / \mathrm{m}^{2}$ gave excellent control of pre-pupae, as well as of females (De Klerk, 1987). Because of great variations in the cyst population, no effect on the cysts could be determined. This product, however, is a chlorinated hydrocarbon and could not be registered in South Africa. Dichloropropene, aldicarb, fenamiphos, carbofuran and oxamyl were found to be ineffective for the control of M. prieskaensis.

Since the pest is rapidly becoming more serious in the area and no pesticide is presently registered for its control, a field trial was conducted over three years to evaluate different contact, fumigant and systemic products. According to Teixeira et al. (2002), good control of Eurhizococcus brasiliensis was achieved with neonicotinoid insecticides, imidacloprid and thiamethoxam in field trials with young grapevines. As this species is also a grapevine-infesting species in Brazil, with females and males congregating on the soil surface for mating, these two products were included in the trial.

\section{MATERIAL AND METHODS}

The trial was conducted near Pofadder $\left(29,127324^{\circ} \mathrm{S} ; 19,396333^{\circ}\right.$ E) along the Orange River in the Northern Cape, in a heavily infested Sultanina (Thompson Seedless) vineyard grafted onto Ramsey, with vine spacing $3.0 \mathrm{~m}$ x $1.8 \mathrm{~m}$ and trained on a gable trellising system. The vines were 12 years old and micro-irrigated. Infested vines were identified during August 2005 by the presence of adult females on the soil surface. These vines were grouped into five randomised blocks of 75 vines each for treatments in the first year, as well as for future treatments. Future treatments depended mostly on results obtained from the previous year. Each treatment was applied randomly in each of the five blocks. Each replicate (plot) consisted of one infested vine with at least one untreated vine between plots in the row. Vines opposite the treated vines in adjacent rows remained untreated. The soil in an area of $1.4 \mathrm{~m} \times 1.4 \mathrm{~m}\left(2 \mathrm{~m}^{2}\right)$ around each treated vine was levelled and the sides were ridged to a height of $100 \mathrm{~mm}$ to $150 \mathrm{~mm}$. 
Pesticides in liquid formulation were dissolved in 10 litres (L) of water and distributed evenly on the soil surface of the plot with a watering can fitted with a spray head. Pesticides in granular formulation were distributed evenly by hand, slightly incorporated into the soil and washed in with $10 \mathrm{~L}$ of water. In 2007, thiomethoxam was applied to a small area $(300 \mathrm{~mm} \times 300 \mathrm{~mm})$ around the stem of the vine at $1.2 \mathrm{~mL} / \mathrm{m}^{2}$ to represent application through drip irrigation. The fumigant, dichloropropene, was applied with a handheld soil-injector gun at a depth of $200 \mathrm{~mm}$ with one application per $300 \mathrm{~mm}$ x $300 \mathrm{~mm}$ area. Within one to two hours after the treatment, another $10 \mathrm{~L}$ of water was applied to each plot to enable the products to move deeper into the soil profile.

The pesticides that were evaluated, along with their formulations, trade names and dosages applied per $\mathrm{m}^{2}$, are shown in Table 1. The products are grouped according to their contact, fumigation or systemic action. The time of application and evaluation (month and year) for pre-pupae and adult females are also shown in Table 1.

In 2006, the contact pesticides for the control of pre-pupae were evaluated on 18 April, three weeks after application. In 2007 and 2008, evaluations were made on 18 and 22 April respectively, two weeks after application. Due to the long withholding period of the systemic pesticides, applications were made three and six weeks after harvest, on 2007-01-10 and 2008-01-30 respectively. The evaluation of these systemic applications for the control of prepupae was made on the same dates in April, as for the contact pesticides.

The same pesticides were evaluated for the control of adult females. In 2006 and 2007, contact pesticides were evaluated on 12 July and 10 July respectively, three weeks after application. In 2008, the evaluations were made on 24 June, two weeks after application. The systemic pesticides applied during January 2007 and 2008 were also evaluated for the control of females on 10 July and 24 June respectively, as for the contact treatments.

The same plots were used for each treatment each year for the application and evaluation of pre-pupae in April, as well as for the females during June and July.

The soil fumigant, dichloropropene A, was applied on 200603-29 for the control of pre-pupae, and dichloropropene B was applied on 2006-06-20 on five different plots for the control of females. Evaluations were done on the same dates as for the contact and systemic products.

During the evaluation of the treatments, the whole treated area of each plot $\left(2 \mathrm{~m}^{2}\right)$ was upturned manually to a depth of

\section{TABLE 1}

Time of application and evaluation of different pesticides for the control of male pre-pupae and adult females of Margarodes prieskaensis in South African vineyards.

\begin{tabular}{|c|c|c|c|c|c|}
\hline Product and formulation & $\begin{array}{l}\text { Trade name } \\
\left(\text { dosage } / \mathbf{m}^{2}\right)\end{array}$ & $\begin{array}{l}\text { Pre-pupae: } \\
\text { time of application }\end{array}$ & $\begin{array}{l}\text { Pre-pupae: } \\
\text { time of evaluation }\end{array}$ & $\begin{array}{l}\text { Females: } \\
\text { time of application }\end{array}$ & $\begin{array}{l}\text { Females: } \\
\text { time of evaluation }\end{array}$ \\
\hline \multicolumn{6}{|l|}{ Contact action } \\
\hline Chlorpyrifos $48 \% \mathrm{ec}^{\mathrm{a}}$ & Dursban $(10 \mathrm{~mL})$ & April 2006 & April 2006 & June 2006 & July 2006 \\
\hline Furfural $90 \%$ ec & Crop Guard (25 mL) & April 2006; 2007 & April 2006; 2007 & June 2006; 2007 & July 2006; 2007 \\
\hline Fenamiphos $40 \%$ ec & Nemacur (10 mL) & April 2006; 2007 & April 2006; 2007 & June 2006; 2007 & July 2006; 2007 \\
\hline Cadusafos $10 \%$ ew $^{\mathrm{b}}$ & Rugby (25 mL) & April 2006; 2007; 2008 & April 2006; 2007; 2008 & June 2006; 2007; 2008 & $\begin{array}{l}\text { July } 2006 ; 2007 ; \\
\text { June } 2008\end{array}$ \\
\hline \multicolumn{6}{|l|}{ Fumigation action } \\
\hline Dichloropropene $100 \% \mathrm{al}^{\mathrm{c}}$ & Telone II (15 mL) & March 2006 & April 2006; 2007; 2008 & - & July 2006; 2007; June 2008 \\
\hline Dichloropropene $100 \%$ al & Telone II (15 mL) & June 2006 & April; 2007; 2008 & June 2006 & July 2006; 2007; June 2008 \\
\hline \multicolumn{6}{|l|}{ Systemic action } \\
\hline Carbofuran $10 \% \mathrm{gr}^{\mathrm{d}}$ & Curaturr (30 gr) & eJan 2007 & April 2007 & Jan 2007 & July 2007 \\
\hline Terbufos $10 \%$ gr & Counter (10 gr) & Jan 2007 & April 2007 & Jan 2007 & July 2007 \\
\hline Fenamiphos $40 \%$ ec & Nemacur $(2.5 \mathrm{~mL})$ & Jan 2008 & April 2008 & Jan 2008 & June 2008 \\
\hline Thiamethoxam 25\% sc ${ }^{f}$ & Actara $(2.4 \mathrm{~mL})$ & Jan 2007 & April 2007; 2008 & Jan 2007 & July 2007; June 2008 \\
\hline Thiamethoxam $25 \%$ sc & Actara $(2.0 \mathrm{~mL})$ & Jan 2008 & April 2008 & Jan 2008 & June 2008 \\
\hline Thiamethoxam $25 \%$ sc & Actara $(1.2 \mathrm{~mL})$ & Jan 2007 & April 2007; 2008 & Jan 2007 & July 2007; June 2008 \\
\hline Imidacloprid 35\% sc & Confidor (15 mL) & Jan 2007 & April 2007; 2008 & Jan 2007 & July 2007; June 2008 \\
\hline Imidacloprid 35\% sc & Confidor (3 mL) & Jan 2008 & April 2008 & Jan 2008 & June 2008 \\
\hline Imidacloprid 35\% sc & Confidor (1.5 mL) & Jan 2008 & April 2008 & Jan 2008 & June 2008 \\
\hline
\end{tabular}

${ }^{a}$ Emulsifiable concentrate, ${ }^{b}$ emulsion oil in water, ${ }^{c}$ undiluted, ${ }^{\mathrm{d}}$ granules, ${ }^{\mathrm{e}}$ January, ${ }^{\mathrm{f}}$ suspension concentrate 
$80 \mathrm{~mm}$ to $120 \mathrm{~mm}$ and all live pre-pupae and females were collected by hand and counted in the field. All live individuals were then returned by distributing them evenly over the whole surface of the plot.

Because of the normally high variation in the cyst population between vines, and the time-consuming method to determine the number of cysts (De Klerk, 1987), no evaluations were made at the cyst stage.

\section{Statistical analyses}

The data were transformed with a square root transformation and then subjected to an analysis of variance using the SAS statistical software (SAS Institute, Inc., 2008). The Shapiro Wilk test (Shapiro \& Wilk, 1965) was used to test the residuals for deviation from normality. In all cases there was not enough evidence against normality for the square root transformed data. Students t-LSD (least significant difference) (Ott, 1998) was calculated at the $5 \%$ significance level to facilitate comparison between treatment means. The percentage control over the untreated control was calculated to simplify a discussion of the results. The percentage control was calculated as: control, minus treatment, divided by control, multiplied by 100 .

\section{RESULTS}

\section{Control of male pre-pupae}

The effect of the different treatments on male pre-pupae over a period of three years is shown in Table 2. The populations in the untreated control plots were very high in each year, with an average of $75 / \mathrm{m}^{2}$. Among the contact pesticides, effective control was achieved each year with cadusafos, at an average control of $85.8 \%$ over three years. In each year the number of pre-pupae was significantly lower than in the untreated control. No differences were evident when the application was made two weeks (2007 and 2008) or three weeks (2006) before evaluation. Chlorpyrifos and furfural gave unsatisfactory control. Fenamiphos, applied as a contact pesticide at $10 \mathrm{~mL} / \mathrm{m}^{2}$, gave satisfactory control $(85.8 \%)$ in the first year (2006), but poor control (35.8\%) after a second application in 2007. Fenamiphos applied in January 2008 as a systemic pesticide at $2.5 \mathrm{~mL} / \mathrm{m}^{2}$ also gave poor control (33.9\%).

\section{TABLE 2}

Mean number of live male pre-pupae of Margarodes prieskaensis per $2 \mathrm{~m}^{2}$ and percentage control after treatment with different pesticides over three consecutive years.

\begin{tabular}{|c|c|c|c|c|c|c|}
\hline \multirow{2}{*}{ Treatment (dosage / $\mathbf{m}^{2}$ ) } & \multicolumn{2}{|c|}{2006} & \multicolumn{2}{|c|}{2007} & \multicolumn{2}{|c|}{2008} \\
\hline & $\operatorname{Mean}(\sqrt{ })$ & $\%$ Control & $\operatorname{Mean}(\sqrt{ })$ & $\%$ Control & $\operatorname{Mean}(\sqrt{ })$ & $\%$ Control \\
\hline \multicolumn{7}{|l|}{ Contact action } \\
\hline Untreated control & $127(10.9)^{\mathrm{a}}$ & 0 & $81(8.5)^{\mathrm{a}}$ & 0 & $239(14.6)^{\mathrm{a}}$ & 0 \\
\hline Chlorpyrifos $(10 \mathrm{~mL})$ & $100(7.6)^{\mathrm{abc}}$ & 21,2 & - & - & - & - \\
\hline Furfural $(25 \mathrm{~mL})$ & $90(8.7)^{\mathrm{ab}}$ & 29,1 & $53(5.1)^{\mathrm{abc}}$ & 34,6 & - & - \\
\hline Cadusafos $(25 \mathrm{~mL})$ & $20(4.4)^{\mathrm{bcd}}$ & $84.3^{*}$ & $17(3.4)^{\mathrm{bcd}}$ & $79,0^{*}$ & $14(2,8)^{\mathrm{cd}}$ & $94,2^{*}$ \\
\hline Fenamiphos $(10 \mathrm{~mL})$ & $18(3,6)^{\mathrm{cd}}$ & $85,8^{*}$ & $52(6.5)^{\mathrm{abc}}$ & 35,8 & - & - \\
\hline \multicolumn{7}{|l|}{ Fumigation action } \\
\hline Dichloropropene A (15 mL) & $0(0)^{\mathrm{d}}$ & $100^{*}$ & $11(2.4)^{\mathrm{cd}}$ & $86,4^{*}$ & $5(2,1)^{\mathrm{d}}$ & $97,9^{*}$ \\
\hline Dichloropropene B (15 mL) & - & - & $9(2,3)^{\mathrm{cd}}$ & $88,9^{*}$ & $16(3.5)^{\mathrm{cd}}$ & $93,3^{*}$ \\
\hline \multicolumn{7}{|l|}{ Systemic action } \\
\hline Carbofuran $(30 \mathrm{~g})$ & - & - & $86(7,8)^{\mathrm{ab}}$ & 0 & - & - \\
\hline Terbufos $(10 \mathrm{~g})$ & - & - & $65(6.1)^{\mathrm{abc}}$ & 19,8 & - & - \\
\hline Fenamiphos $(2.5 \mathrm{~mL})$ & - & - & - & - & $158(12,0)^{\mathrm{a}}$ & 33,9 \\
\hline Thiamethoxam $(2,4 \mathrm{~mL})$ & - & - & $10(1,9)^{\mathrm{cd}}$ & $87,7^{*}$ & $51(6,4)^{\mathrm{bc}}$ & $78,7^{*}$ \\
\hline Thiamethoxam $(2,0 \mathrm{~mL})$ & - & - & - & - & $56(6,9)^{\mathrm{bc}}$ & $76,6^{*}$ \\
\hline Thiamethoxam $(1,2 \mathrm{~mL})$ & - & - & $64(7,2)^{\mathrm{ab}}$ & 21,0 & $137(10,7)^{\mathrm{ab}}$ & 42,9 \\
\hline Imidacloprid (15 mL) & - & - & $0(0)^{\mathrm{d}}$ & $100^{*}$ & $35(4,9)^{\mathrm{cd}}$ & $85,4^{*}$ \\
\hline Imidacloprid $(3,0 \mathrm{~mL})$ & - & - & - & - & $12(3,2)^{\mathrm{cd}}$ & $95,0^{*}$ \\
\hline Imidacloprid $(1,5 \mathrm{~mL})$ & - & - & - & - & $4(1,5)^{d}$ & $98,3^{*}$ \\
\hline $\operatorname{LSD}(P=0.05)$ for $(\sqrt{ })$ & \multicolumn{2}{|c|}{$(4,7)$} & \multicolumn{2}{|c|}{$(4,8)$} & \multicolumn{2}{|c|}{$(4,3)$} \\
\hline
\end{tabular}

$(\sqrt{ })$ Square root transformation: Means followed by different letters differ significantly at the $5 \%$ level of probability

* Differs statistically $(5 \%$ level) from the control 
The contact fumigant, dichloropropene A, gave excellent control for three years after only one application, in March 2006. The percentage control was still $97.9 \%$ in the third year. Excellent control of the pre-pupae was also obtained over two years with one application of dichloropropene B in June 2006. The average control for the two treatments over three years was $93,3 \%$. The mean number of live pre-pupae was significantly lower than in the untreated control in each year. Dichloropropene is phytotoxic and all the treated vines were dead three months after treatment. The few pre-pupae still present after application were probably from cysts occurring deeper in the soil than the fumigant could penetrate.

The systemic pesticides carbofuran and terbufos gave unsatisfactory control. Thiomethoxam at $2.4 \mathrm{~mL} / \mathrm{m}^{2}$ gave good control $(87.7 \%)$ in the first year after treatment in 2007 . The effect of the treatment was still evident in the second year after treatment (2008), with $78.7 \%$ control. In both cases the mean number of live pre-pupae was significantly less than in the untreated control. With a dosage of $2.0 \mathrm{~mL} / \mathrm{m}^{2}$ applied in 2008, the percentage control was also high $(76.6 \%)$. However, unsatisfactory control was obtained with a dosage of $1.2 \mathrm{~mL} / \mathrm{m}^{2}$ in 2008 . Unsatisfactory control was also obtained in 2007 when this dosage was applied only on a small area around the stem of the vine.

Imidacloprid at $15 \mathrm{~mL} / \mathrm{m}^{2}$ gave $100 \%$ control in the first year (2007) and $85.4 \%$ in the second year without a follow-up treatment. Single applications in 2008 of $3.0 \mathrm{~mL} / \mathrm{m}^{2}$ and $1.5 \mathrm{~mL} /$ $\mathrm{m}^{2}$ also gave excellent control, of $95.0 \%$ and $98,3 \%$ respectively. The mean number of live pre-pupae in each treatment was significantly lower than in the untreated control. The treatments did not differ statistically from each other.

\section{Control of adult females}

The effect of the different treatments on adult females over a period of three years is shown in Table 3 . The number of live females in the untreated control plots was high in each year, with an average of $25 / \mathrm{m}^{2}$. None of the contact pesticides provided significant control of the females. Cadusafos, which gave effective control of the pre-pupae, did not control adult females

\section{TABLE 3}

Mean number of live adult females of Margarodes prieskaensis per $2 \mathrm{~m}^{2}$ and percentage control after treatment with different pesticides over three consecutive years.

\begin{tabular}{|c|c|c|c|c|c|c|}
\hline \multirow{2}{*}{ Treatment (dosage / $\mathbf{m}^{2}$ ) } & \multicolumn{2}{|c|}{2006} & \multicolumn{2}{|c|}{2007} & \multicolumn{2}{|c|}{2008} \\
\hline & $\operatorname{Mean}(\sqrt{ })$ & $\%$ Control & $\operatorname{Mean}(\sqrt{ })$ & $\%$ Control & $\operatorname{Mean}(\sqrt{ })$ & $\%$ Control \\
\hline \multicolumn{7}{|l|}{ Contact action } \\
\hline Untreated control & $34(5,7)^{\mathrm{a}}$ & 0 & $29(5,3)^{\mathrm{c}}$ & 0 & $86(9,0)^{\mathrm{a}}$ & 0 \\
\hline Chlorpyrifos $(10 \mathrm{ml})$ & $67(6,9)^{\mathrm{a}}$ & 0 & - & - & - & - \\
\hline Furfural $(25 \mathrm{~mL})$ & $29(5,1)^{\mathrm{ab}}$ & 14,7 & $38(5,4)^{\mathrm{c}}$ & 0 & - & - \\
\hline Cadusafos $(25 \mathrm{~mL})$ & $61(7,7)^{\mathrm{a}}$ & 0 & $169(11,8)^{\mathrm{a}}$ & 0 & $67(6,9)^{\mathrm{ab}}$ & 22,1 \\
\hline Fenamiphos $(10 \mathrm{~mL})$ & $60(7,4)^{\mathrm{a}}$ & 0 & $74(8,1)^{b}$ & 0 & - & - \\
\hline \multicolumn{7}{|l|}{ Fumigation action } \\
\hline Dichloropropene A (15 mL) & $10(2,9)^{\mathrm{bc}}$ & 70,6 & $6(2,1)^{\operatorname{def}}$ & $79,3 *$ & $2(1,0)^{\mathrm{d}}$ & $97,7 *$ \\
\hline Dichloropropene B (15 mL) & $2(0,9)^{\mathrm{c}}$ & $94,1^{*}$ & $4(2,0)^{\mathrm{def}}$ & $86,2 *$ & $3(1,7)^{\mathrm{cd}}$ & $96,5^{*}$ \\
\hline \multicolumn{7}{|l|}{ Systemic action } \\
\hline Carbofuran (30 g) & - & - & $31(5,2)^{\mathrm{c}}$ & 0 & - & - \\
\hline Terbufos $(10 \mathrm{~g})$ & - & - & $19(4,3)^{\mathrm{cd}}$ & 34,5 & - & - \\
\hline Fenamiphos $(2.5 \mathrm{~mL})$ & - & - & - & - & $98(8,5)^{\mathrm{a}}$ & 0 \\
\hline Thiamethoxam $(2,4 \mathrm{~mL})$ & - & - & $3(1,5)^{\mathrm{ef}}$ & $89,7 *$ & $17(3,6)^{\mathrm{bcd}}$ & $80.2 *$ \\
\hline Thiamethoxam $(2,0 \mathrm{~mL})$ & - & - & - & - & $17(4,0)^{\mathrm{bcd}}$ & $80,2 *$ \\
\hline Thiamethoxam $(1,2 \mathrm{~mL})$ & - & - & $15(3,6)^{\mathrm{cde}}$ & 48,3 & $56(6,5)^{\mathrm{ab}}$ & 34,9 \\
\hline Imidacloprid (15 mL) & - & - & $1(0,8)^{\mathrm{f}}$ & $96,6^{*}$ & $10(2,2)^{\mathrm{cd}}$ & $88,4^{*}$ \\
\hline Imidacloprid $(3,0 \mathrm{~mL})$ & - & - & - & - & $17(3,5)^{\mathrm{bcd}}$ & $80,2 *$ \\
\hline Imidacloprid (1,5 mL) & - & - & - & - & $25(4,5)^{\mathrm{bc}}$ & $70,9 *$ \\
\hline $\operatorname{LSD}(P=0.05)$ for $(\sqrt{ })$ & \multicolumn{2}{|c|}{$(3,1)$} & \multicolumn{2}{|c|}{$(3,0)$} & \multicolumn{2}{|c|}{$(3,4)$} \\
\hline
\end{tabular}

( $\sqrt{ })$ Square root transformation: Means followed by different letters differ significantly at the $5 \%$ level of probability

* Differs statistically ( $5 \%$ level) from the control 
even with three consecutive applications over three years on the same plots.

Dichloropropene A and B, applied once in March 2006 and June 2006 respectively, resulted in excellent control for three consecutive years, with an average of $87.4 \%$. The number of females was statistically lower than in the untreated control in each year at the $5 \%$ level, except during 2006 , when the significance was at the $10 \%$ level.

The systemic pesticides carbofuran and terbufos were unsuccessful in controlling the females. No control was obtained with fenamiphos applied as a systemic pesticide. Thiamethoxam at $2.4 \mathrm{~mL} / \mathrm{m}^{2}$ gave good control $(89.7 \%)$ in the first year after treatment in 2007. With no follow-up treatment, control was still $80.2 \%$ in 2008. Effective control was also obtained in 2008 with a dosage of $2.0 \mathrm{~mL} / \mathrm{m}^{2}$. The mean number of females was significantly lower than in the untreated control, and the two dosages did not differ statistically. However, poor control was obtained with a dosage of $1.2 \mathrm{~mL} / \mathrm{m}^{2}$ in 2008. Thiamethoxam, applied in 2007 at $1.2 \mathrm{~mL} / \mathrm{m}^{2}$ on a small area of $300 \mathrm{~mm} \times 300$ $\mathrm{mm}$ around the stem of the vine, also resulted in poor control.

One application of imidachloprid at $15 \mathrm{~mL} / \mathrm{m}^{2}$ gave $96.6 \%$ control in the first year (2007). Without any further applications, excellent control of $88.4 \%$ was still obtained in 2008. Dosages of $3.0 \mathrm{~mL}$ and $1.5 \mathrm{~mL}$ in 2008 resulted in good control of $80.2 \%$ and $70.9 \%$ respectively. The mean number of live females for each treatment was significantly lower than in the untreated control and did not differ statistically from each other.

\section{DISCUSSION}

The results show that no or poor control of M. prieskaensis was obtained with chlorpyrifos, furfural, fenamiphos, carbofuran and terbufos. Cadusafos at $25 \mathrm{~mL} / \mathrm{m}^{2}$ was effective for the control of male pre-pupae. Application should be applied at the start of leafdrop in the last week of March or the first week of April. Cadusafos was, however, not effective for the control of females.

Dichloropropene was very effective for the control of pre-pupae as well as females. The best time of application was in April, when the pre-pupae emerged. As dichloropropene is phytotoxic, it can only be used before an infested block is replanted or when a few single infested vines need to be replaced.
Excellent control of pre-pupae as well as females was obtained with thiamethoxam at $2.4 \mathrm{~mL} / \mathrm{m}^{2}$ and $2.0 \mathrm{~mL} / \mathrm{m}^{2}$ respectively, as well as with imidacloprid at $15 \mathrm{~mL} / \mathrm{m}^{2}, 3.0 \mathrm{~mL} / \mathrm{m}^{2}$ and even 1.5 $\mathrm{mL} / \mathrm{m}^{2}$. These systemic pesticides should be applied after harvest in January/February, at the time when the new annual populations of cysts are actively feeding on the roots and when translocation in the vines is still active.

As only a small percentage of a population of cysts develops into pre-pupae and females annually, and as cysts could lie in the soil for long periods without feeding, treatment with these contact and systemic products needs to be repeated in subsequent years. The population density needs to be determined on an annual basis after treatment.

At this stage, none of these products is registered for the control of Margarodes in South Africa.

\section{LITERATURE CITED}

Ben-Dov, Y., 2005. A systematic catalogue of the scale insect family Margarodidae (Hemiptera: Coccoidea) of the world. Intercept Limited, Wimborne, UK, 400pp.

De Klerk, C.A., 1985. Occurrence of South African species of Margarodes Guilding (Homoptera: Coccoidea: Margarodidae) with special reference to vine infesting species. Phytophylactica 17, 215-216.

De Klerk, C.A., 1987. Chemical control of Margarodes prieskaensis (Jakubski) (Coccoidea: Margarodidae) on grapevines. S. Afr. J. Enol. Vitic. 8, 11-15.

De Klerk, C.A. \& Vermeulen, A.K., 2007. Life cycle of Margarodes prieskaensis (Jakubski) (Coccoidea: Margarodidae) on table grapes in the Northern Cape, South Africa. In: Proc. $5^{\text {th }}$ International Table Grape Symposium, November 2007, Somerset West, South Africa. pp. 139 - 141

Du Toit, G.D.G., 1975. Notes on the biology and behaviour of Sphaeraspis prieskaensis Jak. (Hemiptera: Coccoidea). A pest on grapevine roots. In: Proc. $1^{\text {st }}$ Congr. Ent. Soc. S. Afr. 1975. pp. 255 - 257.

Ott, R.L., 1998. An introduction to statistical methods and data analysis. Duxbury Press, Belmont, CA. pp $807-837$.

SAS Institute Inc., 2008. SAS Version 9.2 SAS Institute Inc, SAS Campus Drive, Cary, North Carolina 27513.

Shapiro, S.S. \& Wilk, M.B., 1965. An analysis of variance test for normality (complete samples). Biometrika 52, 591-611.

Teixeira, I., Botton, M. \& Loeck, A.E., 2002. Avaliação de inseticidas visando ao controle de Eurhizococcus bransiliensis (Hempel) (Hemiptera: Margarodidae) em novos plantios de videira. Neotrop. Entomol. 31(3), 457-461. 